\title{
A PAEAN TO KENTE, THE REMIX
}

Kwadwo Opoku-Agyemang

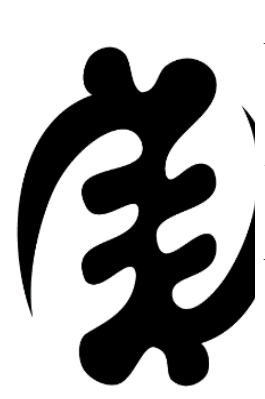

A folkloric delight and the quintessential pourquoi tale, the story of kente is told in the rarest of fabric through color, texture, pattern, vector, scale, balance and symbol. Each solo strand is abundantly furnished with an almost divine manifesto.

All across West Africa kente's etiology has many versions. Each variation is set in a time so olden and fecund that even the history of our world stretched ahead of us then, not behind, and time itself was yet to learn to walk the face of the clock.

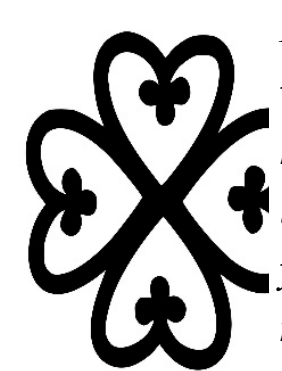

Perhaps the best known rendering of kente's origin story in Ghana is of a hunter whose defeated search for game all day and all night long in the forbidden forest left him thoroughly famished and frustrated. Finally, he comes to rest, if it can be called that, under a giant odum tree. Here he is, stretched out and tired in the bone. His young life seemed to him the graveyard of all hope. In that half state of dire earth and mournful man, a light rain begins to fall, even as the sun continues to beat down. Hanging between wet sleep and dry wakefulness, his head sags and his eyelids droop.

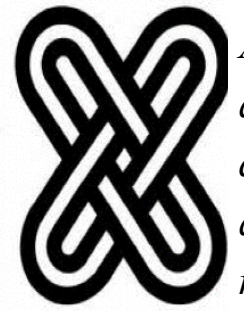

A charged tenor of drizzle and sun displays a spider's web forming in the branches and brambles near the man's head. The arachnid's handicraft catches ripening droplets of the rain, fashioning a kaleidoscope of color. Within the forming web the afternoon dewdrops are finely refracted in shards of light, thus creating a wondrous marketplace of exploding colors as never seen before.

He watches transfixed. It is as if the colors within the web are alive in hues that reach

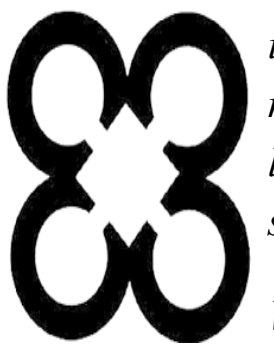
into each other, combing and blending into shapes and slivers and designs that neither time nor mind could ever have promised. Right before him, along the ribs and lines of the spiderweb, a fable of living form and color seems to rise and tell of something immanent, limpid and pellucid.

Wait just wait a minute: could this be a trick, another one of the tall tales of that ubiquitous West African trickster, the ultimate webmaster, Kweku ananse the spider, putative weaver of the world wide web?

The mesmerized hunter gazed in wonderment at the heavenly sight unfolding under the eight limbs of the spider. Such translucence in the weave, the weft and the warp!

In that entranced state the man promised himself to duplicate this same woven artifact in the warmth of his home and hut. Suddenly, he felt alive, present at the 
And that he did.

Upon his return home he built himself a thatch workshop and he planted in the center of that room a loom he had fabricated. From the harmattan season to the rainy season and back, for many days and nights and months he worked, using only the best kind of silk and guided only by the inspiration of the spider's web. And his loom sang the wise old ditty:

Kro kro kro hi ko

Kro kro kro hi ko

Kro kro kro hiko

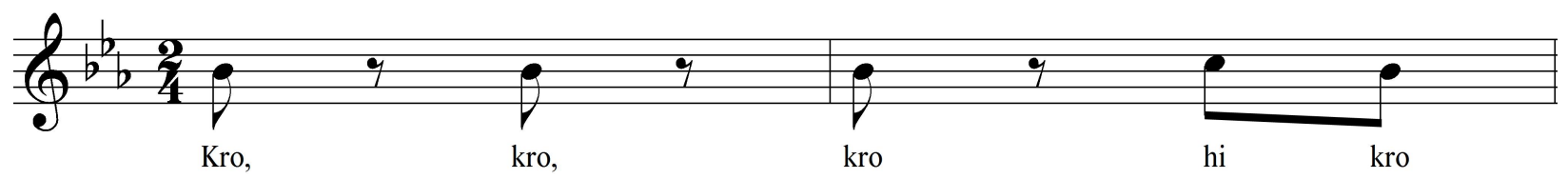

The cadence of the loom so engaged the man that in time he abandoned the hunting game altogether, and the master predator became a questing apprentice poet of the loom.

He applied his hunter's wiles to the hunt for the subtle beauties of the imagination. He read the wind for color and rhythm, sought to replicate the texture of the lynx's fur in his silks. The aromas emanating from his wife's kitchen became like intoxicating wines. His new jungle became the imagination. He threaded the spoor to the lair of the silken spool. He improvised, formed and reformed many designs, sometimes simple as a child's doodle, sometimes intricate beyond measure.

He called his creation kente, and the final version of these, his best ever composition, he named adwenasa. Those of us who have witnessed and have been touched by adwenasa intuit that this bundled yarn, simple threads of inspiration and happiness, somehow possesses the power and colors that can tame the madness in the world around us and sooth the troubled soul within.

Adwenasa: the name alone fulfills all appetites, sates all desires. Its suffix, the morpheme asa, is about closure, absolute finality. It means: what has been done has left nothing else to be done.

The key term adwen contains a pun: on the one hand it is a verb of work which refers to the weaving process itself. But in its other meaning adwen denotes the kingdom of the wise and of the imagination, the vast spectrum of the brain, the seat of the creative urge within the artist. This is the primal artistic impulse and its source, the myth of creation that wills into place what before was not. 
Thus, adwenasa speaks for the artistic endeavor and its fulfillment: the ancient maker's fluent reach beyond our diurnal grasp, the graceful curve into the realm of things so pristine, so beautiful that they leave the witness at once befuddled and enlightened.

Adwenasa tells of the imagination, the poet's endless parsing, kente's magical concatenation of colors and symbols so wonderful and so fierce that even the earth god, Asaase Yaa herself, is often left delightfully gasping at what wondrous affects her creature, this poet of silken colors and shades, a mere mortal, has so kentefully conjured into being.

Drop mic: this is kente, this is Cape Coast, and this is our remix. 